\title{
Current imaging of childhood urinary infections: prospective survey
}

\author{
A M K Rickwood, H M Carty, T McKendrick, M P L Williams, M Jackson, D W Pilling, A Sprigg
}

\begin{abstract}
Objectives-To assess whether ultrasonography alone is adequate for routine screening of childhood urinary infection, whether clinical features determine the need for further investigations, and which investigations are most appropriate.

Design-Prospective survey of children with proved urinary infection and a preinvestigation record of clinical features. Ultrasonography and intravenous urography were routine, with choice of further studies determined by ultrasonographic findings.
\end{abstract}

Setting - A children's hospital and two district general hospitals in Mersey region.

Main outcome measures-Sensitivity and specificity of ultrasonography both generally and in relation to clinical features. Accuracy of intravenous urography compared with radioisotope examinations.

Results-Specificity of ultrasonography was good (99\% (95\% confidence interval $96 \%$ to $100 \%)$ ) but sensitivity modest $(43 \%(32 \%$ to $55 \%))$, principally with respect to detecting vesicoureteric reflux and renal scarring. Among older children (aged 2-10 years) with positive ultrasound results and fever or vomiting the sensitivity in detecting reflux (with and without renal scarring) was $78 \%(62 \%$ to $89 \%)$ and the specificity $69 \%(60 \%$ to $78 \%)$; in detecting renal scarring (with and without reflux) the sensitivity was $100 \%(80 \%$ to $100 \%)$ and specificity $65 \%(56 \%$ to $\mathbf{7 4 \%}$ ). Renal scarring and obstructive uropathies were better assessed by radioisotope examinations than by intravenous urography.

Conclusions-Ultrasonography alone is inadequate for routine screening of childhood urinary infection. Though further investigations remain advisable in infants, in older children they can be restricted to a minority who have positive ultrasound examinations or have had fever or vomiting. Radioisotope examinations largely eliminate the need for intravenous urography.

\section{Introduction}

Some $30-50 \%$ of children presenting with urinary infection have urinary anomalies, principally vesicoureteric reflux, often with associated renal scarring. ${ }^{1.3}$ Because anomalies cannot be excluded clinically, ${ }^{+}$it is advisable that all cases be investigated, traditionally by intravenous urography and micturating cystourethrography. Other means of imaging the urinary tract now exist, some more sensitive and others less invasive than contrast radiology. Radioisotope examinations have advantages over intravenous urography - static renal scintigraphy in detecting pyelonephritic renal scarring ${ }^{56}$ and dynamic diuresis renography in distinguishing obstructive from non-obstructive uropathies. ${ }^{78}$ Ultrasonography has obvious merits for children, and when findings are normal further investigation may deserve pursuit only in infants or older children who have recurrent infections or symptoms of pyelonephritis. ${ }^{910}$ Advocates accept that this may overlook a (hopefully) small number of children with vesicoureteric reflux or renal scarring. ${ }^{910}$

As imaging methods proliferate so do policies of investigating childhood urinary infection. Accordingly we undertook a systematic prospective survey comparing the various methods and addressing three principal issues:

(1) Is ultrasonography alone sufficient for routine screening?

(2) If not, could clinical features determine the need for further investigations?

(3) Which further investigations are most appropriate?

\section{Patients and methods}

We surveyed children up to 10 years of age consecutively presenting to this hospital and to the paediatric departments at St Helens and Whiston Hospitals with a symptomatic, bacteriologically proved, urinary infection (single organism, colony count $>10^{5}$ organisms $/ \mathrm{ml}$, and significant pyuria (white cell count $>5 \times 10^{6} / 1$ in boys or $>40 \times 10^{6} / 1$ in girls)). Midstream samples were obtained in older children and bag specimens (Hollister U-Bag) in infants.

Details of relevant clinical information were recorded on a form before investigation. All children underwent ultrasonography, then intravenous urography, with the choice of further investigations being determined by the ultrasonographic findings. Cystography and static renal scintigraphy (dimercaptosuccinic acid labelled with technetium-99m) were performed when ultrasonography and intravenous urography gave normal results or showed abnormalities in renal size, outline, or echotexture. Cystography was also performed when distal ureteric dilatation was detected and was followed by static scintigraphy in the presence of vesicoureteric reflux or by dynamic diuresis renography ( ${ }^{4 \% \mathrm{~m}} \mathrm{Tc}$-mercaptoacetyltriglycine) otherwise. Cases of pure pelvic hydronephrosis were examined by dynamic renography only. Static renal scintigraphy was always deferred until at least a month after the urinary infection had cleared.

In the statistical analyses proportions are presented with continuity corrected $95 \%$ confidence intervals ${ }^{11}$; contingency table analysis was undertaken for calculation of $\chi^{2}$ statistics for equality of probability and trend. ${ }^{12}$ Sensitivity and specificity ${ }^{12}$ rates for the performance of ultrasonography were derived when appropriate.

\section{Results}

The survey ran from early 1987 to late 1989 , when 200 children (141 girls, 59 boys) had been studied. Forty seven children had been admitted as emergencies 
TABLE I-Urinary anomalies detected in 200 children with urinary tract infection

\begin{tabular}{lrl}
\hline Anomaly & \multicolumn{2}{l}{ No of patients } \\
\hline Vesicoureteric reflux & & $49 \star$ \\
$\quad$ Gradef: & 12 & \\
$\quad$ I & 18 & \\
II & 9 & \\
III & 9 & \\
IV & 1 & 9 \\
Renal scarring, no reflux & & $9 \ddagger$ \\
Supravesical obstruction & 5 & \\
Ureterovesical junction & 4 & 9 \\
Pelviureteric junction & 3 & \\
Duplex system anomalies & 2 & \\
Lower polar reflux & 2 & \\
Ureteric ectopia & 2 & \\
Ureterocoele & 2 & \\
Incomplete, uncomplicated & 1 & \\
Other & & \\
$\quad$ Fraley's syndrome & & \\
Horseshoe kidney & & \\
\hline Total & & \\
\hline
\end{tabular}

$\star$ In 20 patients (26 kidneys) associated with renal scarring.

tIn bilateral reflux (19 cases) worse grade of reflux is listed when nonconcordant (eight cases).

fObstruction not confirmed by renographic criteria in three cases.

TABLE II-Performance of ultrasonography in relation to other imaging methods

\begin{tabular}{|c|c|c|c|}
\hline & \multicolumn{2}{|c|}{$\begin{array}{l}\text { Findings with other } \\
\text { methods }\end{array}$} & \multirow[b]{2}{*}{ Total } \\
\hline & + & - & \\
\hline Findings on ultrasonography $\left\{\begin{array}{l}+ \\
-\end{array}\right.$ & $\begin{array}{l}34 \\
45^{\star}\end{array}$ & $\begin{array}{r}1 \\
120\end{array}$ & $\begin{array}{r}35 \\
165\end{array}$ \\
\hline Total & 79 & 121 & 200 \\
\hline
\end{tabular}

Sensitivity of ultrasonography $43 \%$ (95\% confidence interval $32 \%$ to $55 \%$ ).

Specificity of ultrasonography $99 \%$ ( $96 \%$ to $100 \%)$. *False negative results on ultrasonography: 26 patients with vesicoureteric reflux grades I and II (four with scarring) and 10 with grades III and IV (eight with scarring), seven with renal scarring and no reflux, and two with incomplete duplex system anomalies.

TABLE III-Symptoms of upper and lower urinary tract infection in 138 children aged $2-10$ years

\begin{tabular}{|c|c|}
\hline Symptom & No of children \\
\hline \multicolumn{2}{|c|}{ Lower urinary tract } \\
\hline Frequency/nocturia & 76 \\
\hline Dysuria & 88 \\
\hline Secondary enuresis & 29 \\
\hline Suprapubic pain & 25 \\
\hline Malodorous urine & 18 \\
\hline
\end{tabular}

Upper urinary tract

General malaise

Vomiting

Fever $\left(\geqslant 38^{\circ} \mathrm{C}\right)$

Central/upper abdominal pain

Loin pain and 153 had been seen as outpatients. Anomalies disclosed by investigation are summarised in table I.

\section{ULTRASONOGRAPHY VERSUS OTHER IMAGING METHODS}

Although ultrasonography detected all obstructive (and pseudo-obstructive) uropathies and complete duplex system anomalies, the examination gave normal results in 36 cases of vesicoureteric reflux, some of them severe, and in seven out of nine cases of isolated renal scarring (table II). In six children a combination of major reflux and renal scarring passed undetected by ultrasonography.

\section{CLINICAL FEATURES VERSUS INCIDENCE OF URINARY ANOMALIES}

Age and sex-The proportion of children with anomalies did not differ significantly between the sexes. A declining trend with age did not reach significance.

Single versus recurrent infection-Most infants and almost all boys presented with their first infection. Among girls aged 2-10 years the incidence of anomalies did not differ between those suffering their first infection $(13 / 35 ; 39 \%$ (95\% confidence interval $21 \%$ to $55 \%)$ ) and those presenting with at least one previous episode $(25 / 70 ; 36 \%$ (25\% to $48 \%))$.

Symptoms were rarely distinctive in the 62 children under 2 years of age; 58 of them presented with fever or vomiting, or both. In older children distinction was possible between symptoms of lower urinary tract infection and those suggesting involvement of the upper renal tracts (table III).

Symptoms, ultrasonography, and incidence of anomaliesTable IV shows the relation of ultrasonographic findings to symptoms in general and to two non-subjective symptoms, fever (temperature $\geqslant 38^{\circ} \mathrm{C}$ ) and vomiting. False negative ultrasound examinations were exclusively of vesicoureteric reflux and renal scarring. Table $\mathrm{V}$ shows the sensitivity and specificity of ultrasonography in detecting these anomalies in patients with positive ultrasound results and symptoms either of upper urinary tract infection or of vomiting or fever, or both.

INTRAVENOUS UROGRAPHY VERSUS RADIOISOTOPE EXAMINATIONS

All renal scarring detected by intravenous urography was also evident on static renal scintigraphy. In 29 children a total of 39 kidneys showed scarring on scintigraphy; an intravenous urogram appeared normal in 16 such cases, including two of severe scarring. Three out of nine cases of apparent obstructive uropathy on contrast radiology did not show obstruction by the criteria of dynamic diuresis renography.

TABLE IV - Performance of ultrasonography in relation to symptoms of urinary infection in 138 children aged 2-10 years

\begin{tabular}{|c|c|c|c|c|c|c|c|c|c|c|c|c|}
\hline & \multicolumn{2}{|c|}{ Upper urinary tract ${ }^{\star}$} & \multirow[b]{2}{*}{ Total } & \multicolumn{2}{|c|}{ Lower urinary tract only } & \multirow[b]{2}{*}{ Total } & \multicolumn{2}{|c|}{ Vomiting or fever, or both $\dagger$} & \multirow[b]{2}{*}{ Total } & \multicolumn{2}{|c|}{ No vomiting or fever $\ddagger$} & \multirow[b]{2}{*}{ Tota } \\
\hline & + & - & & + & - & & + & - & & + & - & \\
\hline Findings on ultrasonography $\left\{\begin{array}{l}+ \\
-\end{array}\right.$ & $\begin{array}{l}13 \\
21\end{array}$ & $\begin{array}{r}0 \\
34\end{array}$ & $\begin{array}{l}13 \\
55\end{array}$ & $\begin{array}{l}7 \\
8\end{array}$ & $\begin{array}{r}0 \\
55\end{array}$ & $\begin{array}{r}7 \\
63\end{array}$ & $\begin{array}{l}11 \\
20\end{array}$ & $\begin{array}{r}0 \\
21\end{array}$ & $\begin{array}{l}11 \\
41\end{array}$ & $\begin{array}{l}9 \\
9\end{array}$ & $\begin{array}{r}0 \\
68\end{array}$ & $\begin{array}{r}9 \\
77\end{array}$ \\
\hline Total & 34 & 34 & 68 & 15 & 55 & 70 & 31 & 21 & 52 & 18 & 68 & 86 \\
\hline $\begin{array}{l}\text { Sensitivity (\%) ( } 95 \% \text { confidence interval) } \\
\text { Specificity }(\%)(95 \% \text { confidence interval) }\end{array}$ & & $\begin{array}{c}39(22 \text { to } 56) \\
100(88 \text { to } 100)\end{array}$ & & & $\begin{array}{c}47(21 \text { to } 73) \\
100(92 \text { to } 100)\end{array}$ & & & $\begin{array}{c}36(19 \text { to } 55) \\
100(81 \text { to } 100)\end{array}$ & & & $\begin{array}{c}50(26 \text { to } 74) \\
100(93 \text { to } 100)\end{array}$ & \\
\hline \multicolumn{13}{|c|}{ True positive, false negative results on ultrasonography } \\
\hline $\begin{array}{l}\text { Vesicoureteric reflux (grade): } \\
\text { I } \\
\text { II } \\
\text { III } \\
\text { IV } \\
\text { Scarring, no reflux } \\
\text { Other }\end{array}$ & $\begin{array}{l}1 \\
1 \\
3(3 \|) \\
2(2 \|) \\
1 \\
5\end{array}$ & $\begin{array}{l}4 \\
5 \\
7(7 \| 1) \\
5\end{array}$ & & $\begin{array}{l}1 \\
1(1 \|) \\
1 \\
4\end{array}$ & $\begin{array}{l}4 \\
3 \\
1\end{array}$ & & $\begin{array}{l}3(3 \|) \\
2(2 \|) \\
1 \\
5\end{array}$ & $\begin{array}{l}3 \\
5 \\
7(7 \|) \\
5\end{array}$ & & $\begin{array}{l}1 \\
2 \\
1(1 \|) \\
1 \\
4\end{array}$ & $\begin{array}{l}5 \\
3 \\
1\end{array}$ & \\
\hline Total & 13 & 21 & & 7 & 8 & & 11 & 20 & & 9 & 9 & \\
\hline
\end{tabular}

$\star$ One or more symptoms with and without symptoms of lower urinary tract infection. tDocumented fever with temperature $\geqslant 38^{\circ} \mathrm{C}$. $\ddagger$ Temperature $<38^{\circ} \mathrm{C}$ or temperature not recorded (10 patients). NNo with associated renal scarring. 
TABLE $\mathrm{v}-$ Sensitivity and specificity of ultrasonography in detecting vesicoureteric reflux and renal scarring in children with positive results on ultrasonography and either one or more upper urinary tract symptoms or fever and vomiting (138 children aged 2-10 years)

\begin{tabular}{|c|c|c|c|c|c|c|c|c|c|}
\hline & \multicolumn{2}{|c|}{$\begin{array}{l}\text { All vesicoureteric reflux with and } \\
\text { without renal scarring }\end{array}$} & \multirow[b]{2}{*}{ Total } & \multicolumn{2}{|c|}{$\begin{array}{l}\text { Vesicoureteric reflux grades III-IV } \\
\text { with and without renal scarring }\end{array}$} & \multirow[b]{2}{*}{ Total } & \multicolumn{2}{|c|}{$\begin{array}{l}\text { Renal scarring with and without } \\
\text { vesicoureteric reflux }\end{array}$} & \multirow[b]{2}{*}{ Tota } \\
\hline & + & - & & + & - & & + & - & \\
\hline Positive ultrasonography or one or more upper tract symptoms $\{$. & $\begin{array}{r}32 \\
8 \\
\end{array}$ & $\begin{array}{l}43 \\
55\end{array}$ & $\begin{array}{l}75 \\
63\end{array}$ & $\begin{array}{r}20 \\
1\end{array}$ & $\begin{array}{l}55 \\
62\end{array}$ & $\begin{array}{l}75 \\
63\end{array}$ & $\begin{array}{r}20 \\
0\end{array}$ & $\begin{array}{l}55 \\
63\end{array}$ & $\begin{array}{l}75 \\
63\end{array}$ \\
\hline Total & 40 & 98 & 138 & 21 & 117 & 138 & 20 & 118 & 138 \\
\hline $\begin{array}{l}\text { Sensitivity }(\%)(95 \% \text { confidence interval }) \\
\text { Specificity }(\%)(95 \% \text { confidence interval })\end{array}$ & & $\begin{array}{l}80(65 \text { to } 91) \\
56(46 \text { to } 66)\end{array}$ & & & $\begin{array}{l}95(76 \text { to } 100) \\
53(44 \text { to } 62)\end{array}$ & & & $\begin{array}{c}100(80 \text { to } 100) \\
53(44 \text { to } 63)\end{array}$ & \\
\hline Positive ultrasonography or fever or vomiting $\left\{\begin{array}{l}+ \\
-\end{array}\right.$ & $\begin{array}{r}31 \\
9\end{array}$ & $\begin{array}{l}30 \\
68 \\
\end{array}$ & $\begin{array}{l}61 \\
77 \\
\end{array}$ & $\begin{array}{r}20 \\
1\end{array}$ & $\begin{array}{l}41 \\
76\end{array}$ & $\begin{array}{l}61 \\
77\end{array}$ &. $\begin{array}{r}20 \\
0\end{array}$ & $\begin{array}{l}41 \\
77\end{array}$ & $\begin{array}{l}61 \\
77\end{array}$ \\
\hline Total & 40 & 98 & 138 & 21 & 117 & 138 & 20 & 118 & 138 \\
\hline $\begin{array}{l}\text { Sensitivity }(\%)(95 \% \text { confidence interval }) \\
\text { Specificity }(\%)(95 \% \text { confidence interval })\end{array}$ & & $\begin{array}{l}78(62 \text { to } 89) \\
69(60 \text { to } 78)\end{array}$ & & & $\begin{array}{l}95(76 \text { to } 100) \\
65(56 \text { to } 74)\end{array}$ & & & $\begin{array}{c}100(80 \text { to } 100) \\
65(56 \text { to } 74)\end{array}$ & \\
\hline
\end{tabular}

\section{Discussion}

The specificity of ultrasonography is excellent so that abnormal results always merit further investigation. Its sensitivity, by contrast, is modest. Though obstructive uropathies and complete duplex system anomalies are efficiently detected, the far more common and sometimes severe examples of vesicoureteric reflux and renal scarring frequently escape notice.

As normal ultrasound examinations do not exclude consequential urinary anomalies, do clinical features indicate which children require further investigation? Below 2 years of age they do not as symptoms are rarely characteristic and almost always comprise an element of constitutional upset, suggesting that the kidneys are affected. Also, the risk of renal scarring is greatest in very young children so that further investigations (cystography, renal scintigraphy) remain routinely advisable. In older children symptoms are more distinctive and of those indicative of upper renal tract infection, the two non-subjective features, fever and vomiting, seem to be as relevant as any. A policy of pursuing further investigations only in children with positive results on ultrasonography or with fever and vomiting would spare most older children this experience at the expense of overlooking a modest number with mainly minor reflux ${ }^{16}$ and still fewer with renal scarring.

Should overlooking minor reflux without scarring cause concern? Almost certainly not, provided that there is no further urinary infection. In girls the chance of this is high, ${ }^{13}$ and a policy of routinely pursuing further investigations in those with recurrent infections ${ }^{10}$ would necessarily subject most to this process. In this series, as in two others, ${ }^{31+}$ the incidence of urinary anomalies in girls did not relate to the number of infections but rather to the associated symptoms. This suggests that children initially presenting with recurrent infections, or representing with a further infection, need additional investigation when ultrasound results are normal only when any episode has been accompanied by fever or vomiting.

When further investigations are indicated which are most appropriate? As have studies specifically addressing the performance of radioisotope examinations, ${ }^{5-8}$ we found that renal scarring is best assessed by static renal scintigraphy and obstructive uropathies by dynamic diuresis renography; the role of intravenous urography is much diminished. In very young children, especially male infants, micturating cystourethrography remains the preferred means of confirming or excluding vesicoureteric reflux, but in older, cooperative children this might be replaced by indirect isotope cystography. ${ }^{15}$

Since the survey we now use ultrasonography with plain abdominal radiography for initial screening because urinary calculi are occasionally overlooked by ultrasonography. Patients with abnormal results are investigated further along the lines adopted by the survey but without routine intravenous urography. When the results of ultrasonography and plain abdominal radiography are normal children under 2 years of age undergo contrast cystography and static renal scintigraphy. Among older children these further investigations are restricted to those in whom infection (including recurrent infection in girls) has been associated with fever or vomiting. This policy, we believe, minimises the number of children requiring invasive investigations while ensuring that consequential urinary anomalies are rarely overlooked.

We thank Dr Celia Cramp and Dr Cynthia Woodhall for their cooperation with the survey.

1 Smellie JM, Hodson CJ, Edwards D, Normand ICS. Clinical and radiologica features of urinary infection in childhood. BMF 1964;ii: 1222-6.

2 Dickinson JA. Incidence and outcome of symptomatic urinary infection in hildren. BMF 1979;i:1330-2.

3 McKerrow W, Davidson-Lamb N, Jones PF. Urinary tract infection in children. BMF 1984;289:299-303.

4 Smellie JM. Acute urinary tract infection in children. BMf 1970;iv:97-100.

5 Merrick MV, Uttley WS, Wild SR. The detection of pyelonephritic scarring in children by radio-isotope imaging. Br f Radiol 1980;53:544-56.

6 Whitear P, Shaw P, Gordon I. Comparison of ${ }^{{ }^{*} \mathrm{~m}} \mathrm{Tc}$ dimercaptosuccinic acid scans and intravenous urography in children. Br F Radiol 1990;63:438-43.

7 O'Reilly PH, Lawson RS, Shields RA, Testa HJ. Idiopathic hrdronephrosisthe diuresis renogram: a new non-invasive method assessing equivocal pelvioureteral junction obstruction. 7 Urol 1979;121:153-5.

8 O'Reilly PH. Diuresis renography 8 years later: an update. $\mathcal{F}$ Urol 1986;136: 993-9.

9 Sherwood T, Whitaker RH. Initial screening of children with urinary tract infection: is plain film radiography and ultrasonography enough? $B M Y$ 1984:288:827.

10 Hanbury DC, Whitaker RH, Sherwood T, Farman P. Ultrasound and plain $\mathrm{x}$-ray screening in childhood urinary tract infection. Br $\mathcal{F}$ Urol 1989;64:

11 Fleiss JL. Statistical methods and proportions. 2nd ed. Chichester: Wiley 1981:29-30

12 Armitage P, Berry G. Statistical methods in medical research. 2nd ed. Oxford: Blackwell Scientific, 1982:371-408

13 Bergstrom T. Sex differences in childhood urinary tract infection. Arch Dis Child 1972;47:227-32

14 Moncrieff $\mathrm{MW}$, Whitelaw R. Value of evstography in urinary tract infections. Arch Dis Child 1976:51:893-5.

15 Peters AM, Morony S, Gordon I. Indirect radio-nuclide cystography demonstrates reflux under physiological conditions. Clin Radiol 1990;41:44-7.

16 International Reflux Study Committee. Medical versus surgical treatment of primary vesicoureteric reflux: a prospective international reflux study in children. 7 Urol 1981:135:277-83.

Accepted 12 December 19911 